\title{
Byssinosis in carpet weavers exposed to wool contaminated with endotoxin
}

\author{
M ÖZESMI, ${ }^{1}$ H ASLAN, ${ }^{1}$ G HILLERDAL, ${ }^{2}$ R RYLANDER ${ }^{3}$ C ÖZESMI, ${ }^{1}$ \\ Y I BARIS ${ }^{4}$
}

From the School of Medicine, ${ }^{1}$ Erciyes University, Kayseri, Turkey, Department of Lung Medicine, ${ }^{2}$ University Hospital, Uppsala, and Department of Hygiene, ${ }^{3}$ University of Gothenburg, Sweden, and the School of Medicine, ${ }^{4}$ Hacettepe University, Ankara, Turkey

ABSTRACT All the 303 full time day workers in a carpet weaving factory were submitted to a physical examination, chest radiography, and vitalograph test, and answered a respiratory questionnaire. Fifty four healthy non-exposed subjects served as controls. Dust concentrations and concentrations of bacterial endotoxin were measured. Of the 303 workers, $259(85.5 \%)$ had airway symptoms and $62(20.5 \%)$ had maximum mid-expiratory flow (MMF) values of less than $60 \%$ compared with $9 \cdot 2 \%$ of the controls. The symptoms in 68 workers $(22 \%)$ were compatible with byssinosis and 36 of these workers underwent vitalography before starting work and after four hours work on Mondays when significant reductions of their $\mathrm{FEV}_{1}$ and MMF were found. Twenty one of these 36 workers were tested on Tuesday and no differences in these measurements were found between measurements before work started and four hours later. The airborne dust concentrations in the factory were high and bacterial endotoxin was found. These findings suggest that a large number of workers in this carpet weaving factory suffer from a disease indistinguishable from byssinosis even though wool is used almost exclusively, the only cotton being the warp. The finding of endotoxin together with the absence of cotton confirms the theory that "byssinosis" is due to bacterial endotoxin rather than to cotton per se.

The knotting of wool carpets is a common industry in Kayseri in Middle Anatolia, Turkey. Only a few studies on wool carpet factories or woollen mills have been published in English and these report an excess of respiratory symptoms. ${ }^{12}$

Obstructive airway disease in workers in textile factories has been recognised since the eighteenth century, when it was described by Ramazzini. The disease has been termed byssinosis and occurs when working with such materials as cotton and flax. The classic symptoms are subjective tightness in the chest and often an independent decrease of lung function on the first day after the weekend or a prolonged absence. These symptoms are often accompanied by coughing and wheezing. ${ }^{3-5}$

The specific aetiological agent in byssinosis is unknown. Previously, it has been suggested that some

Accepted 27 August 1986 factor in the cotton bract may be responsible and in experimental settings extracts thereof have induced epithelial changes in the trachea and bronchospasm. ${ }^{6-8}$ If this is true exposure to wool should not cause byssinosis. Other possible aetiological agents are bacteria, in particular the endotoxin which some of them produce. ${ }^{910}$

A pilot study in a carpet factory indicated that symptoms similar to byssinosis were present despite the fact that wool was almost exclusively used. It was therefore decided to investigate the workers of the carpet factory further and to measure the concentration of airborne dust and the concentration of endotoxin within the dust.

\section{Material and methods}

A carpet factory with 710 employees was selected for the study. All 303 full time day workers ( 241 men, 62 women) were investigated. Their mean age was 36 (range 22 to 48 ).

The wool arrives at the factory in large packages that are opened, mixed, and then washed (figure). 


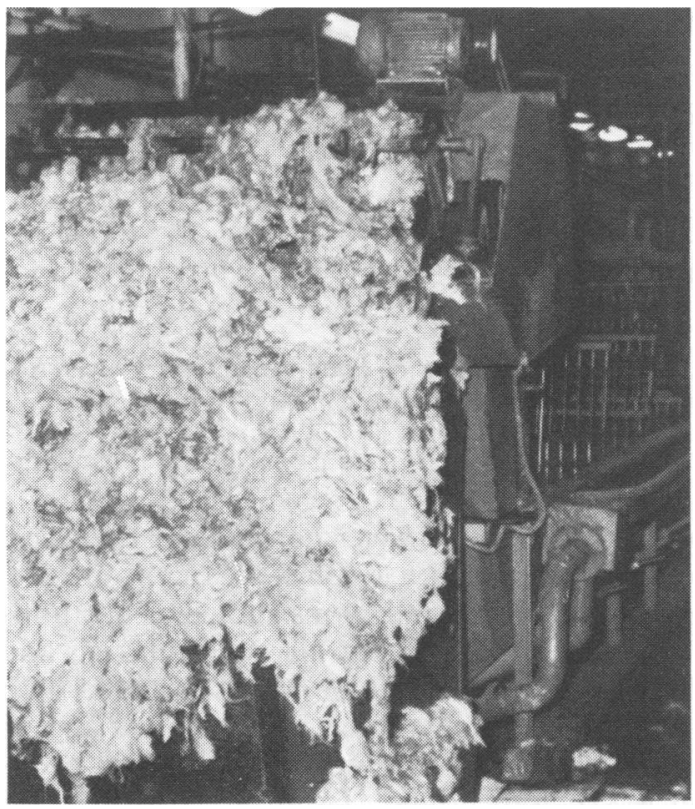

Wool before being washed in the washroom.

After this, it is carded and spun. The next step is to colour the spun wool and, after drying, the carpets are woven. Most workers are in the weaving section (table 1). Cotton is used only for the warp and this occurs in the weaving section.

Seventy three per cent of the workers were smokers and $27 \%$ non-smokers. Most, $66 \%$, had worked at the factory for less than five years, $23 \%$ for five to 10 years, and $7 \%$ for more than 10 years.

Forty workers had previously worked with cotton. There were no differences in lung function or symptoms between these workers and the 263 workers who had worked only with wool. Thus the two groups were not separated for the analyses.

Each of the 303 workers completed the standardised questionnaire of the American Thoracic Society (ATS/DLD) ${ }^{11}$ and was submitted to physical examination and lung function tests with the Vitalograph. Three expiratory curves in the upright position were obtained, and from the best curve vital capacity (VC), forced expiratory volume in one second $\left(\mathrm{FEV}_{1}\right)$, maximum mid-expiratory flow (MMF), and maximum breathing capacity (MBC) were calculated. A miniature chest $x$ ray picture (posteroanterior view) was taken, but unfortunately for technical reasons only 237 workers could be so examined.

Fifty four students and medical personnel with a median age of 30 (range 22-37) served as controls. There were 32 men and 22 women of whom 27 were smokers and 27 never smokers. All controls under-
Özesmi, Aslan, Hillerdal, Rylander, Özesmi, Bari $\stackrel{\substack{c \\ c}}{\frac{\omega}{\bar{c}}}$

Table 1 Dust concentrations, endotoxin concentrations, and relative numbers of workers employed at various procedures

\begin{tabular}{|c|c|c|c|}
\hline Procedure & $\begin{array}{l}\text { Dust } \\
\text { concentration } \\
\left(\mathrm{mg} / \mathrm{m}^{3}\right)\end{array}$ & $\begin{array}{l}\text { Endotoxin } \\
\text { concentration } \\
(\mu g / g \text { wool })\end{array}$ & $\begin{array}{l}\% \text { Of work forc } \\
\text { employed }\end{array}$ \\
\hline $\begin{array}{l}\text { Opening } \\
\text { Washing } \\
\text { Carding } \\
\text { Spinning } \\
\text { Weaving } \\
\text { End preparation }\end{array}$ & $\begin{array}{l}3 \cdot 4 \\
2 \cdot 8 \\
4 \cdot 4 \\
1 \cdot 7 \\
2.6 \\
2 \cdot 5\end{array}$ & $\begin{array}{l}7 \cdot 8-10 \cdot 7 \\
0 \cdot 7 \\
5 \cdot 7-15 \cdot 6 \\
0 \cdot 3 \\
5 \cdot 7-31 \cdot 2 \\
0 \cdot 1\end{array}$ & $\begin{array}{r}3.5 \\
1.2 \\
14.0 \\
1.2 \\
65.5 \\
14.6\end{array}$ \\
\hline
\end{tabular}

went chest $x$ ray examination and completed the्ष questionnaire.

In most of the workers with symptoms mainly on Mondays and in 18 symptom free workers vital- ography was performed before starting work on af Monday and after four hours work. Several were tested similarly on a Tuesday.

In workers with reduced lung function a cutaneous test with wool antigen (Institut Pasteur, production ${ }^{\mathrm{C}}$ extrait allergenique du laine) was performed. Asymptomatic carpet weavers and non-exposed workerso (office personnel, gardeners, etc,) served as controls: $: v$ They had $0 \cdot 1 \mathrm{ml}$ of antigen diluted 1/10000 injected intracutaneously in the forearm and $0.1 \mathrm{ml}$ of phys iological saline was injected as a control. An oe dematous reaction of $1 \mathrm{~cm}^{2}$ was regarded as positive

Measurements of dust concentrations were per.D formed in the different departments with a filter tech nique. Endotoxin concentrations in dust collected from different sites of the factory representing different procedures were measured by the Limulus method. ${ }^{12}$

Student's $t$ test and chi square test were used to evaluate the statistical significance between differen groups.

\section{Results}

\section{DUST CONCENTRATIONS}

Depending on the type of work being carried out, the airborne dust concentrations varied between 1.7 and: $4.4 \mathrm{mg} / \mathrm{m}^{3}$. Carding and weaving were the dustiest procedures, and it was also at these sites that the highest concentrations of endotoxin were found and where most workers were employed (table 1). The amount of endotoxin in the dusts ranged from $0 \cdot 1$ to $31 \cdot 2 \mu \mathrm{g} / \mathrm{g}$.

\section{CHEST RADIOGRAPHY}

Thirty five $(15 \%)$ of the films of the 237 workers who had chest radiography showed abnormalities, but none of these was of the type usually associated with? pulmonary fibrosis. 
Table 2 Nunber of symptoms (cough, increased sputum, dyspnoea, and wheezing) in workers and controls. (Percentages in parentheses)

\begin{tabular}{lllllrr}
\hline No of symptoms & 0 & 1 & 2 & 3 & 4 & Total \\
\hline Controls & $24(44)$ & $14(26)$ & $7(13)$ & $3(6)$ & $6(11)$ & $54(100)$ \\
Workers & $44(15)$ & $51(17)$ & $54(18)$ & $70(23)$ & $84(28)$ & $303(100)$ \\
\hline
\end{tabular}

Table 3 Numbers of smokers and non-smokers with different number of sumptoms. (Percentages in parentheses)

\begin{tabular}{|c|c|c|c|c|c|c|}
\hline No of symptoms & 0 & 1 & 2 & 3 & 4 & Total \\
\hline \multicolumn{7}{|l|}{ Smokers: } \\
\hline $\begin{array}{l}\text { Controls } \\
\text { Workers }\end{array}$ & $9(33)$ & $7(26)$ & $4(15)$ & $5(19)$ & $2(7)$ & 27 \\
\hline \multicolumn{7}{|l|}{ Non-smokers: } \\
\hline Controls & $15(56)$ & $7(25)$ & & $5(19)$ & & 27 \\
\hline Workers & $24(29)$ & $25(30$ & & $34(41)$ & & 83 \\
\hline
\end{tabular}

\section{PHYSICAL FINDINGS}

In nine workers (3\%) some abnormal physical findings were found at chest auscultation. In two of these fine basal crepitating rales were heard.

\section{SYMPTOMS}

Altogether $259(85.5 \%)$ workers complained of one or more respiratory symptoms compared with 30 $(55.5 \%)$ of the controls. This difference was statistically significant $(p<0.001)$. Of the different symptoms, cough, increased amounts of sputum, dyspnoea, and wheezing were significantly more common among the symptomatic workers than the symptomatic controls (table 2).

\section{SYMPTOMS RELATED TO SMOKING}

Among the smokers, a significantly larger number of workers than controls complained of symptoms $(p<0.01)$. The same was true among non-smokers $(p<0.01)$. As expected, smokers-both workers and controls-had a larger number of symptoms (table 3 ).

Table 4 Lung function tests: percentages of workers with the indicated values

\begin{tabular}{|c|c|c|c|}
\hline & \multicolumn{3}{|c|}{ Per cent of predicted } \\
\hline & $>90$ & $60-89$ & $<60$ \\
\hline \multicolumn{4}{|c|}{ Vital capacity: } \\
\hline Workers & $72 \cdot 6$ & $27 \cdot 4$ & \\
\hline \multicolumn{3}{|c|}{ Forced expiratory volume in one second: } & \\
\hline $\begin{array}{l}\text { Workers } \\
\text { Controls }\end{array}$ & $\begin{array}{l}63.7 \\
76.0\end{array}$ & $\begin{array}{l}33 \cdot 3 \\
24 \cdot 1\end{array}$ & $3 \cdot 0$ \\
\hline \multicolumn{4}{|c|}{ Maximum mid-expiratory flow: } \\
\hline Workers & $39 \cdot 6$ & 39.9 & $20 \cdot 5$ \\
\hline Controls & $70 \cdot 3$ & $20 \cdot 3$ & $9 \cdot 2$ \\
\hline \multicolumn{4}{|c|}{ Maximum breathing capacity: } \\
\hline Workers & $52 \cdot 8$ & $\mathbf{4 4 \cdot 2}$ & $3 \cdot 0$ \\
\hline Controls & $75 \cdot 9$ & $22 \cdot 2$ & 1.9 \\
\hline
\end{tabular}

\section{LUNG FUNCTION TESTS}

In nine workers $(3 \%)$ the $\mathrm{FEV}_{1}$ was reduced to less than $60 \%$ of the predicted value and in 62 workers $(20.5 \%)$ the MMF was less than $60 \%$ predicted (table 4). All nine workers in whom the $\mathrm{FEV}_{1}$ was less than $60 \%$ of that predicted were smokers as were 47 of those with reduced MMF.

\section{SYMPTOMS AND LUNG FUNCTION RELATED TO DUSTINESS OF WORK AND WORK YEARS}

There were no significant differences in the number of symptoms between workers occupied on the different procedures, although some trends were observed (table 5). MMF values below $60 \%$ were found in $29 \%$ of those working in the carding section, which was the dustiest, and in $23 \%$ of those in the weaving section. These differences were not significant.

MMF values of less than $60 \%$ of predicted were found in $50 \%$ of the workers who had spent 10 years or more in the factory, in $19 \%$ of those who had spent five to 10 years, and in $17 \%$ of those who had spent less than five years. The difference between those exposed for more than 10 years and those exposed for less is significant $(p<0.01)$.

\section{"MONDAY SYMPTOMS",}

Sixty eight workers complained of "Monday disease" - that is, symptoms that were worse some hours after starting work on Mondays. In 36 of these and in 18 who did not have such symptoms vitalography was

Table 5 Percentage numbers of workers with different numbers of symptoms, distributed by working procedure

\begin{tabular}{llll}
\hline Symptoms & Carding & Spinning & Weaving \\
\hline None & $8 \cdot 3$ & $19 \cdot 7$ & $13 \cdot 3$ \\
$1-2$ & $33 \cdot 3$ & $37 \cdot 9$ & $30 \cdot 4$ \\
$3-4$ & $58 \cdot 3$ & $42 \cdot 4$ & $56 \cdot 3$ \\
\hline
\end{tabular}


performed before work on Mondays and after four hours work. In the group with symptoms significant reductions of the mean VC $(p<0.05)$, FEV $_{1}$ $(p<0.01)$, and MMF $(p<0.05)$ were found. There were no changes in these variables among the controls. In 21 of the 36 tested workers with symptoms and positive Monday findings the test was repeated on Tuesday with a negative result.

\section{INTRACUTANEOUS TEST}

The intracutaneous test was performed on 61 workers with Monday symptoms and on 15 asymptomatic workers. Thirty $(49 \%)$ of those with symptoms and six $(40 \%)$ of those without showed a positive result. This difference is not significant.

\section{Discussion}

Of the workers, only two had crepitating rales and in 237 workers for whom chest $x$ ray films were available there were no radiological findings compatible with pulmonary fibrosis. No restrictive lung function changes were observed. Thus there was no evidence of hypersensitivity pneumonitis and the symptoms and finding are more compatible with an obstructive disease.

The dust concentrations in the factory were high The maximum recommended dust level is $1 \mathrm{mg} / \mathrm{m}^{3},{ }^{3}$ but in this factory the mean level was greater than this and the maximum was $4.37 \mathrm{mg} / \mathrm{m}^{3}$. Although only 16 workers had worked for more than 20 years in the factory, $85 \%$ had symptomatic airway disease. As expected, the smokers were more affected. The high dust concentration in the factory could give rise to an "industrial bronchitis,"13 and in earlier studies on wool exposure symptoms compatible with such nonspecific irritation of the dust have in fact been noted. ${ }^{45}$ The Monday symptoms found in $22 \%$ of the workers are not compatible with uncomplicated bronchitis but are a classic byssinosis. ${ }^{1-3}$

The characteristic of byssinosis is the development of symptoms that become worse on Mondays after starting work; for the rest of the week the symptoms are less disturbing. With chronic disease, a picture of chronic obstruction develops without the classic Monday symptoms. ${ }^{314}$ At this stage the diagnosis can only be made from the history; if the patient claims previously to have had Monday symptoms this is compatible with the diagnosis. This particular question was unfortunately not clearly put in the present survey, but the relatively high figure of $22 \%$ with Monday symptoms and the confirmation of this finding by objective means makes it probable that at least a considerable proportion of the other workers with chronic obstructive symptoms also suffer from byssinosis.
In a previous investigation in a wool mill symptoms $\frac{\widehat{\alpha}}{3}$ of byssinosis could not be detected. ${ }^{15}$ Earlier studies? in the wool industry have shown a high prevalence of $\vec{c}$ : cough or obstructive disease, or both, but the particu- $-\frac{}{-}$ lar aspect of "Monday disease" has not been emphasised. ${ }^{45}$

Studies during recent years have shown that the $\frac{\vec{\sigma}}{\widetilde{R}}$ amount of bacterial endotoxin in cotton dust is the $\propto$ best predictor of acute airway responses and the de-ळึ velopment of chest tightness. ${ }^{1016}$ The symptoms of $\vec{\circ}$ byssinosis originally attributed to dust from cottonand flax have been described in other environments $\vec{\omega}$ with a high concentration of endotoxins such as spaces humidified by water contaminated with Gram-专 negative bacteria ${ }^{17}$ and swine confinement buildings. In the carpet factory studied endotoxins were present $\stackrel{+}{+}$ in all dust samples and the concentrations in some of ${ }^{v}$ them were equal to or exceeded those found in highly contaminated cotton. ${ }^{10}$ The finding of classic bys-o sinosis in this factory, where cotton was totally absent ${ }^{-}$ up to the weaving stage (where cotton material is used in the warp), offers further support for this patho- $-\frac{}{<}$ genetic theory. The source of the endotoxin con- tamination was not investigated but it could be $\infty$ contaminated with ground dust during shearing or.during storage or transportation.

The findings also indicate that dust in carpet factories is a risk factor for health that should be con-ō trolled.

\section{References}

1 Allardice JT, Clarke EC, Jones RD. A study of the prevalence of $\overrightarrow{ }$ epistaxis and respiratory symptoms in carpet backwinders. $\boldsymbol{F}_{0}$ Soc Occup Med 1983;33:36-41.

2 Zuskin E, Valice E, Bouhuys A. Effect of wool dust on respiratory function. Am Rev Respir Dis 1976;114:705-9.

3 Schilling RSF, Hughes JPW, Dingwall FT, Gilson JC. Epidemiological study of byssinosis among Lancashire cotton workers. Br J Ind Med 1956;12:217-27.

4 Bouhuys A. Byssinosis: scheduled asthma in the textile industry. Lung 1976;154:3-16.

5 Morgan WKC, Seaton A. Occupational lung diseases. Philadel- 0 phia: WB Saunders, 1980:274-320.

6 Schlachter EN, Brown S, Zuskin E, Buck M, Kolack B, Bouhuys D A. Airway reactivity in cotton bract-induced bronchospasm. Am Rev Respir Dis 1981;123:273-6.

7 Russel JA, Gilberstadt ML, Rohrbach MS. Constrictor effect of cotton bract extract on isolated canine airway. Am Rev Respir Dis 1982;125:727-33.

8 Cloutier MM, Lesmial KL, Russel JA, Rohrbach MS. Effect of cotton bract extract on canine tracheal epithelium and shunt $\sigma$ pathway. Am Rev Respir Dis 1984;130:1087-90.

9 Rylander R. Bacteria as etiological agents in byssinosis and othefo lung disease. Eur $J$ Respir Dis 1982;63, suppl 23:34-46.

10 Rylander R, Haglind P, Lundholm M. Endotoxin in cotton dust and respiratory function decrement among cotton workers inan experimental cardroom. Am Rev Respir Dis 1985;131: 209-13.

11 Comstock WP, Tockman SM, Helsing SK, Hennsy MK. Standardized respiratory questionnaires: comparison of the old $\vec{D}$ with the new. Am Rev Respir Dis 1979;119:45-9. 
12 Rylander R, Morey P. Airborne endotoxins in industries processing vegetable fibers. Am Ind Hyg Assoc J 1982;43:811-2.

13 Morgan WKC. Industrial bronchitis. Br J Ind Med 1978;35: 285-91.

14 Kamat SR, Kamat GR, Sadpelor VY, Lobo E. Distinguishing byssinosis from chronic obstructive palmonary disease. Am Rev Respir Dis 1981;124:31-40.

15 Cinkotai FF, Lockwood MG, Rylander R. Airborne micro- organisms and prevalence of byssinotic symptoms in cotton mills. Am Ind Hyg Assoc J 1977;38:554-9.

16 Rylander R, Haglind P. Exposure of cotton workers in an experimental cardroom with reference to airborne endotoxins. Environ Health Perspect (in press).

17 Rylander R, Haglind P. Airborne endotoxins and humidifier disease. Clin Allergy 1984;14:109-12.

\section{Correspondence and editorials}

The British Journal of Industrial Medicine welcomes correspondence relating to any of the material appearing in the journal. Results from preliminary or small scale studies may also be published in the correspondence column if this seems appropriate. Letters should be not more than 500 words in length and contain a minimum of references. Tables and figures should be kept to an absolute minimum. Letters are accepted on the understanding that they may be subject to editorial revision and shortening.

The journal now also publishes editorials which are normally specially commissioned. The Editor welcomes suggestions regarding suitable topics; those wishing to submit an editorial, however, should do so only after discussion with the Editor. 